\title{
Prevalence of some nematode parasites in the Egyptian tortoise (Testudo kleinmanni)
}

Abd El- All, A.A.; Gamal- Eldein, M.A ${ }^{\mathbf{1}}$ and Nehal M. Elassy ${ }^{1}{ }^{*}$ Department of Parasitology, ${ }^{1}$ Department of Wildlife and Zoo Medicine, Faculty of Veterinary Medicine, Suez Canal University

*Corresponding author: Nehal Mohammed Elassy

Adress: Department of Wildlife and Zoo Medicine, Faculty of Veterinary Medicine, Suez Canal University

Mobile No.: 01005883248

\begin{abstract}
:
A total of 50 apparently healthy Egyptian tortoises were taken from five different localities in Egypt, from: Port Saied pet animal shops, Elsayeda Aesha market, Ismailia pet animal shops, Cairo pet animal shops and Giza pet animal shops. The parasitological examination revealed the presence of nine nematode parasites, Tachygonetria paradentata, Alaeuris asirensis, Thelandros massae, Thelandros species, Physaloptera species, Atractis species, Mehdiella microstoma, Mehdiella species and Angusticaecum holopterum. The prevalence of these nematode parasites in the five groups was tabulated. This study recommended the periodical examination of tortoises for parasitic infestation and improving their environment in captivity.
\end{abstract}

\section{Introduction:}

Captivity is stressful, predisposing tortoises to parasitic infestations. Crowding of hosts in captivity, creating an increased risk of reinfection, may lead to heavy parasitism and severe clinical disease and even death (Sátorhelyi and Sréter, 1993).

Wild and captive reptiles are frequently infected with various endoparasites, many of which are minimally pathogenic. However, the stress of captivity, improper husbandry and poor sanitation can lead to serious diseases and ultimately death in heavily parasitized captive reptiles (Wilson and Carpenter, 1996).

Gastrointestinal tract parasitism is the most common disorder of the digestive system seen in pet reptiles. So, reptiles are hosts to a huge number of parasites (Bernard and Upton, 1994 and Willette et al, 1995).

The aim of this work is to study the prevalence and morphology of some nematode parasites that can affect the species Egyptian tortoises in captivity.

\section{Material and methods:}

50 Egyptian tortoises (Testudo kleinmanni) were collected from 
five different localities in Egypt, 10 from Port Saied (group 1), 10 Ismailia (group 2), 10 Cairo (group 3), 10 Giza pet animal shops (group 4) and 10 Elsayeda Aesha market (group 5).

These tortoises were subjected to ante-mortem and post-mortem parasitological examination. Fecal examination was carried out by direct smear method and flotation technique according to Levine (1985). The visceral organs especially gastrointestinal tract were examined carefully for helminth parasites and any worms were collected, washed and counted according to Reid (1962) and Bisset et al, (1996). The nematode parasites were fixed in 5\% glycerolalchol $70 \%$, cleared in lactophenol and permanently mounted in glycerol- gelly according to Pence and Dowler (1979).

Results and Discussion:

Prevalence of the detected helminth parasites

Parasitological findings of the examined tortoises revealed the identification of nine helminthes parasites. Results in Table (1) recorded the total prevalence of infection was (100\%) in all groups, worm count was $3820,3312,1517$, 3944 and 3705 while the mean intensity of infection of the examined groups was 382, 331.2, $151.7,394.4$ and 370.5 respectively in the examined groups.

The prevalence of the detected nematode parasites in groups 1,2 , 3, 4 and 5 was, Tachygonetria paradentata 70, 70, 40, 90 and 80\%; Alaeuris asirensis 40, 20, 20, 60 and 30\%; Thelandros massae 20, $10, \quad 0.0, \quad 30, \quad 60$ and $0.0 \%$; Thelandros species 50, 20, 0.0, 50 and $0.0 \%$; Physaloptera species 10, 0.0, 0.0, 50 and 50\%; Atractis species $0.0,70,0.0,70$ and $60 \%$; Mehdiella microstoma 50, 30, 30, 20 and 60\%; Mehdiella species 100, $80, \quad 70, \quad 100$ and $100 \%$ and Angusticaecum holopterum 0.0, 0.0, $10,0.0$ and $0.0 \%$ in the five groups respectively (Table, 2$)$.

Traversa et al (2005) in their study on 13 Testudo hermanni hermanni, found $3(23 \%)$ tortoises harboured Tachygonetria longicollis, 1(7.7\%) harboured Tachygonetria conica and $\quad 1(7.7 \%) \quad$ harboured Tachygonetria palearcticus, while in the present study, Tachygonetria paradentata was found in a range of $40-90 \%$ in the five groups. These results were nearly similar to that of Rataj et al (2011) who found Tachygonetria species in $33.3 \%$ $92.5 \%$ in tortoises.

The high prevalence of Tachygonetria up to $90 \%$ in the current study concurs with the findings of Baker et al (1998) who evaluated eleven fecal samples from wild Sonoran Desert tortoises where Tachygonetria species (pinworm) ova were identified in all fecal samples.

In addition, Mader (1996); Bouamer and Morand, (2002) and Dove et al (2002) confirmed that Tachygonetria species is common in herbivore reptiles and this 
oxyurid nematode have developed a commensal relationship with its host.

Traversa et al (2005) recorded the oxyurid nematode Atractis dactyluris in $53.8 \%$ of Testudo hermanni hermanni and in $16.6 \%$ of Testudo hermanni boettgeri while in the current study, Atractis species was found in Egyptian tortoises in a range of $0.0-70 \%$ in the five tortoises groups.

The presence of Atractids in tortoises is of importance since these nematodes have been caused significant morbidity and mortality in tortoises bred in captivity; also Atractids are viviparous, being able to induce internal autoinfections, this enhancing their pathogenicity in stressed or debilitated animals (Rideout et al, 1987).

Also, Traversa et al (2005) found Mehdiella uncinata in $7.7 \%$ of Testudo hermanni hermanni while in the current study, Mehdiella species was found in $70-100 \%$ of the tested tortoises and, Mehdiella microstoma was found in $20-60 \%$ of the examined Egyptian tortoises. In the same study, Alaeuris numidica adults were found in the feces of two Testudo graeca (15.3\%), while four animals harbored the ascarid Angusticaecum holopterum (30.6\%), also Alaeuris numidica and of Mehdiella microstoma adult worms were retrieved in the feces of two Testudo marginata (33.3\%), these results are in line with that of the current study as Alaeuris asirensis was found in a range of $20-60 \%$ and Angusticaecum holopterum in $0.0-10 \%$ of the examined tortoises.

Occurrence of Angusticaecum holopterum in the current study concurs with results of Holt et al (1979) who found specimens of Anguisticecum species in the same species of tortoise and without clinical signs, the reason for the no appearance of clinical signs here is due to low parasite burden but if it is high may result in gastrointestinal disturbance and obstruction of colon and can be of life threatening (Pannikar and Sproston 1941; Forstner 1960 and Sprent 1980).

From the data shown in Table (2), Angusticaecum holopterum was found in $10 \%$ of the cases lower than that obtained by Rataj et al (2011) who found Angusticaecum species in Testudo graeca and $T$. hermanni in $20.3 \%$, but was higher than that obtained by Pasmans et al (2008) in $2.7 \%$ of captive chelonians.

The current study findings concerning oxyurids were somewhat similar to that obtained by Rataj et al (2011) who found these frequently in Hermann's tortoises (92.5\%). Also, Satorhelyi and Sreter(1993) found oxyurids (Atractis, Mehdiella, Tachygonetria and Thaparia species) in (69\%) of 71 tortoises. On the other hand, our findings of Angusticaecum holopterum (10\%) were much higher than their findings (2.8\%). Although lots of parasites were recorded in the current study, all 
examined tortoises were apparently healthy, this is may be because of what Mitchel and Figueroa (2005) reported that gastrointestinal helminthes are frequently found in chelonians and generally are mild pathogens also, Jacobson (2007) added that GIT helminthes rarely involved as significant pathogen.

Morphological criteria of the helminth parasites:

The detected nematode parasites were identified as seven oxyurids, one spirurid and one ascarid. The oxyurid nematodes were, Tachygonetria paradentata (Fig. 1, 2, 3\& 4) Alaeuris asirensis (Fig. 5 to 10), Thelandros massae (Fig.11 to 13), Thelandros species (Fig.14 to 16), Atractis species (Fig.19 to 22), Mehdiella microstoma (Fig. 23\&24), Mehdiella species (Fig. 25 to 28). The detected spirurid nematode was Physaloptera species (Fig. 17\&18). The ascarid nematode was Angusticaecum holopterum (Fig. 29 to 32).

These nematodes were identified depending upon the morphological criteria, size and diagnosis of both adult male and female and their organs especially the cephalic extremity and esophagus cited in keys and literatures (Travassos, 1925; Adamson and Nasher, 1984; Barus and Johnson, 1973; Baylis, 1920; Thapar, 1925; Bouamer and Morand, 2002; Markov et al., 1962; Sprent, 1980).

All the detected nematodes were identified to species level except four types, Thelandros species, Atractis species, Mehdiella species and Physaloptera species which were identified to the genus level only because the dimensions and morphological criteria of these four nematodes were overlapping with other species in the genera.

Table (1): The total prevalence and mean intensity of infection of the detected nematode parasites in the all examined groups

\begin{tabular}{|c|c|c|c|c|}
\hline $\begin{array}{c}\text { Group } \\
\text { No. }\end{array}$ & $\begin{array}{c}\text { No. of infested } \\
\text { tortoises }\end{array}$ & $\begin{array}{c}\text { Total } \\
\text { prevalence }\end{array}$ & $\begin{array}{c}\text { Worm } \\
\text { count }\end{array}$ & $\begin{array}{c}\text { Mean Intensity of } \\
\text { infection }\end{array}$ \\
\hline 1 & 10 & $100 \%$ & 3820 & 382 \\
\hline 2 & 10 & $"$ & 3312 & 331.2 \\
\hline 3 & 10 & $"$ & 1517 & 151.7 \\
\hline 4 & 10 & $"$ & 3944 & 394.4 \\
\hline 5 & 10 & $"$ & 3705 & 370.5 \\
\hline Total & & $"$ & 16298 & 325.96 \\
\hline
\end{tabular}


Table (2): The prevalence of the detected nematode parasites in all groups

\begin{tabular}{|c|c|c|c|c|c|c|c|c|c|c|}
\hline \multirow[b]{2}{*}{$\begin{array}{l}\text { Helminth nematode } \\
\text { species }\end{array}$} & \multicolumn{5}{|c|}{ No. of infested tortoises } & \multicolumn{5}{|c|}{ Prevalence } \\
\hline & $\begin{array}{l}\text { Gr. } \\
1\end{array}$ & $\begin{array}{l}\text { Gr. } \\
2\end{array}$ & $\begin{array}{l}\text { Gr. } \\
3\end{array}$ & $\begin{array}{l}\text { Gr. } \\
4\end{array}$ & $\begin{array}{l}\text { Gr. } \\
5\end{array}$ & $\begin{array}{l}\text { Gr. } \\
1\end{array}$ & $\begin{array}{l}\text { Gr. } \\
2\end{array}$ & $\begin{array}{l}\text { Gr. } \\
3\end{array}$ & $\begin{array}{l}\text { Gr. } \\
4\end{array}$ & $\begin{array}{l}\text { Gr. } \\
5\end{array}$ \\
\hline $\begin{array}{l}\text { Tachygonetria } \\
\text { paradentata }\end{array}$ & 7 & 7 & 4 & 9 & 8 & $\begin{array}{l}70 \\
\% \\
\end{array}$ & 70 & 40 & 90 & 80 \\
\hline Alaeuris asirensis & 4 & 2 & 2 & 6 & 3 & 40 & 20 & 20 & 60 & 30 \\
\hline Thelandros massae & 2 & 1 & 3 & 6 & 0 & 20 & 10 & 30 & 60 & 0 \\
\hline Thelandros species & 5 & 2 & 0 & 5 & 0 & 50 & 20 & 0 & 50 & 0 \\
\hline $\begin{array}{l}\text { Physaloptera } \\
\text { species }\end{array}$ & 1 & 0 & 0 & 5 & 5 & 10 & 0.0 & 0 & 50 & 50 \\
\hline Atractis species & 0 & 7 & 0 & 7 & 6 & 0.0 & 70 & 0 & 70 & 60 \\
\hline $\begin{array}{l}\text { Mehdiella } \\
\text { microstoma }\end{array}$ & 5 & 3 & 3 & 2 & 6 & 50 & 30 & 30 & 20 & 60 \\
\hline Mehdiella species & 10 & 8 & 7 & 10 & 10 & $\begin{array}{l}10 \\
0\end{array}$ & 80 & 70 & $\begin{array}{l}10 \\
0\end{array}$ & $\begin{array}{l}10 \\
0\end{array}$ \\
\hline $\begin{array}{l}\text { Angusticaecum } \\
\text { holopterum }\end{array}$ & 0 & 0 & 1 & 0 & 0 & 0.0 & 0.0 & 10 & 0.0 & 0.0 \\
\hline
\end{tabular}
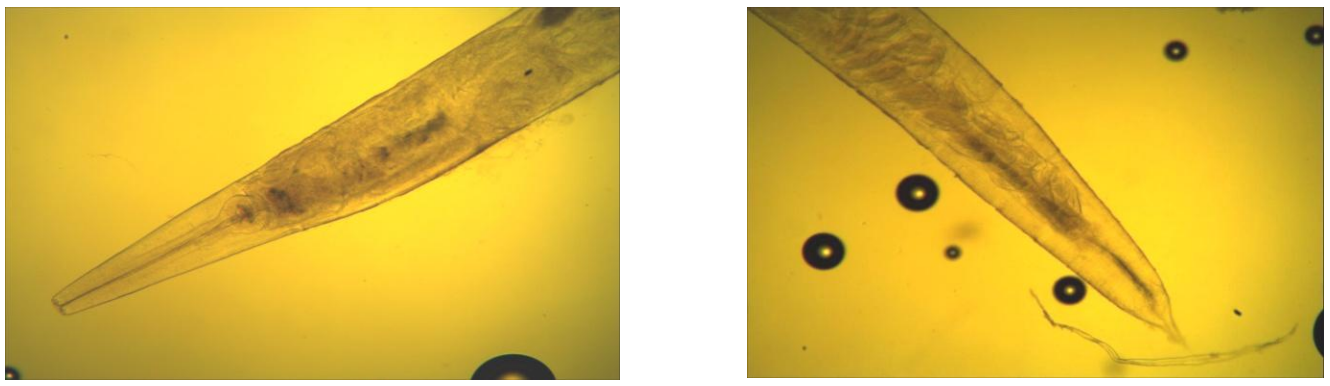

Fig.(1): Tachygonetria paradentata Female; anterior end X10

Fig. (2): Tachygonetria paradentata Female; posterior end X10
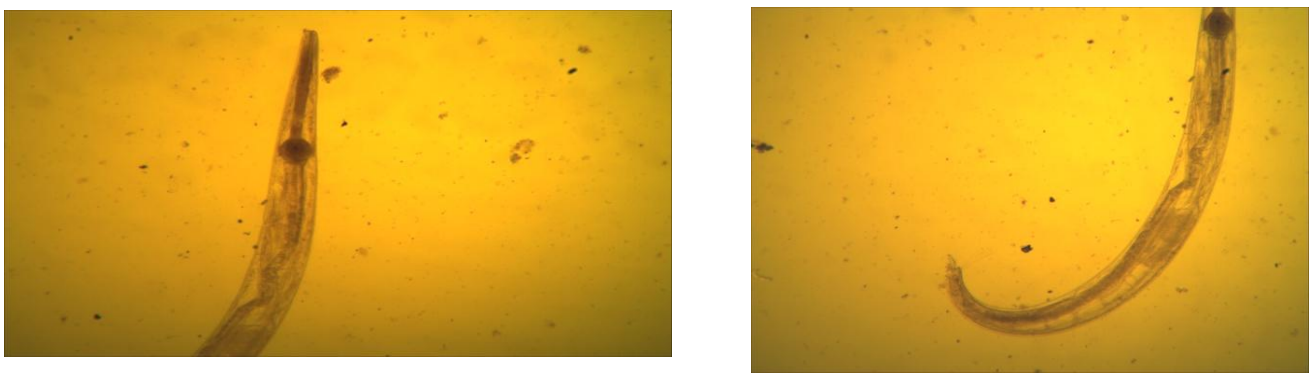

Fig.(3): Tachygonetria paradentata Male; anterior end X10 Male; Fig.(4): Tachygonetria paradentata posterior end X10 

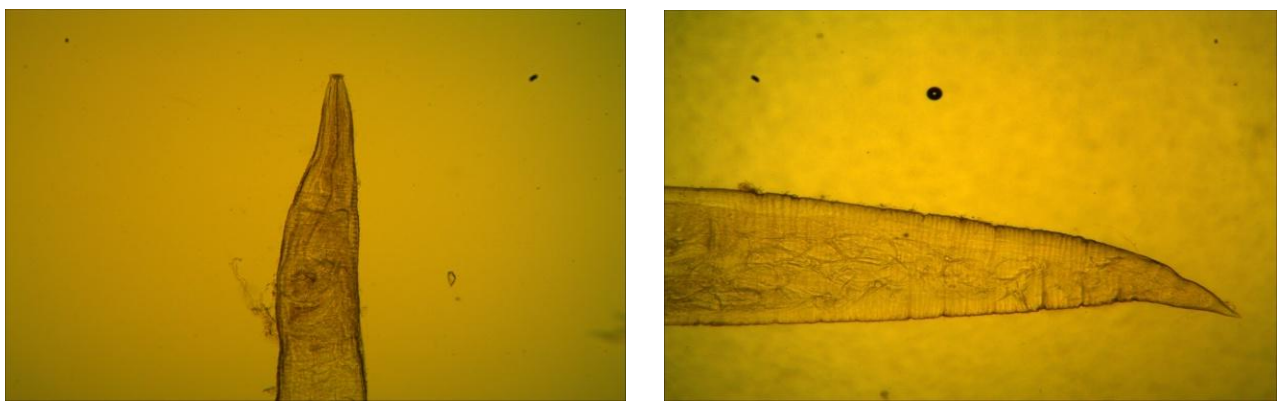

Fig. (5): Alaeuris asirensis Female; anterior end X10

Fig. (6): Alaeuris asirensis Female; posterior end X10
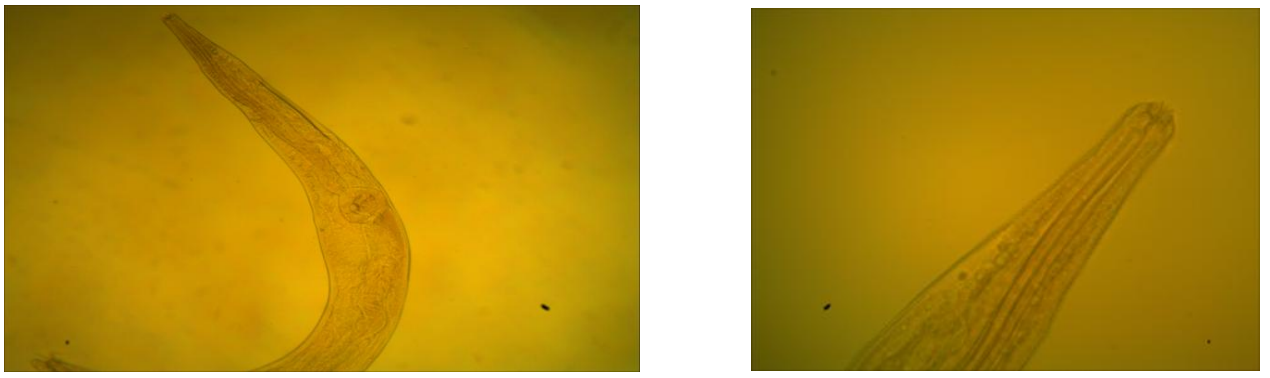

Fig. (7): Alaeuris asirensis Male; anterior end X10

Fig. (8): Alaeuris asirensis Male; anterior end X40
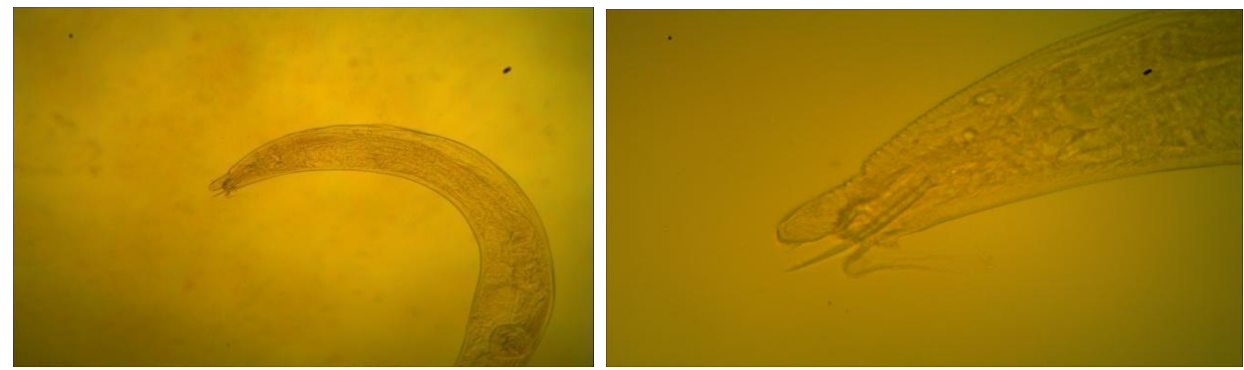

Fig. (9): Alaeuris asirensis Male; posterior end X10

Fig. (10): Alaeuris asirensis Male; posterior end X40
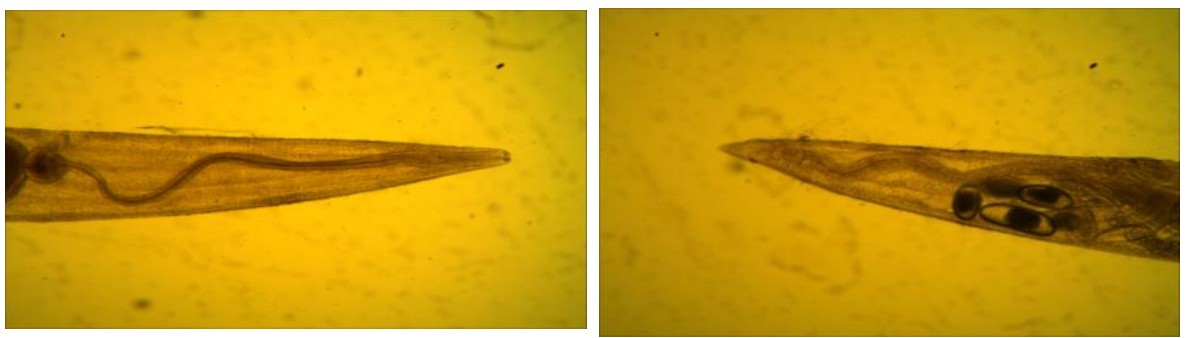

Fig. (11): Thelandros massae Female; anterior end X10

Fig. (12): Thelandros massae Female; posterior end X10 

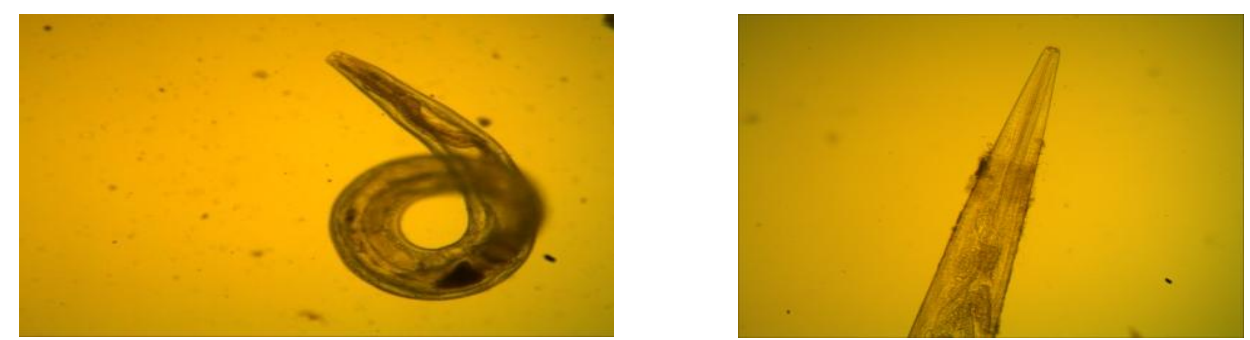

Fig. (13): Thelandros massae male X4

Fig. (14): Thelandros species Female; anterior end X10
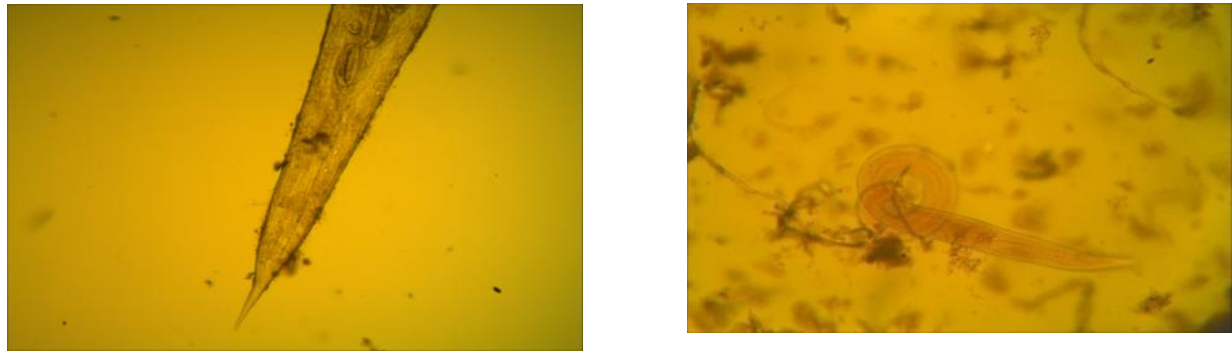

Fig. (15): Thelandros species Female; posterior end X10 Fig. (16): Thelandros species male X4
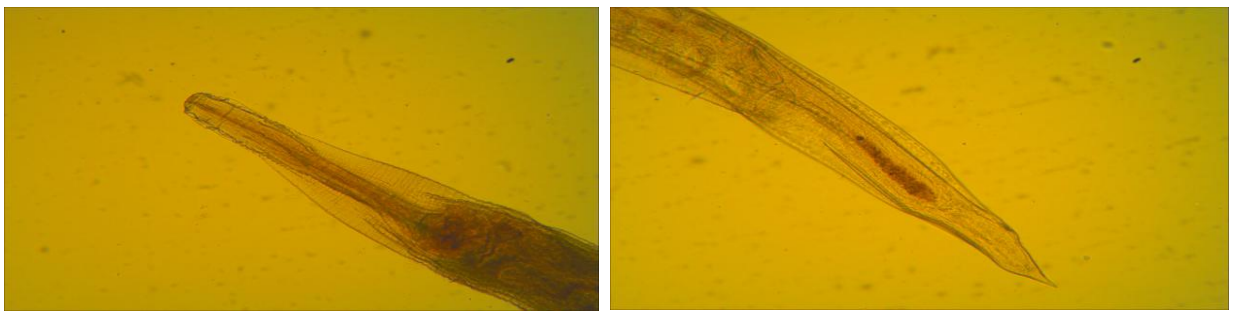

Fig. (17): Physaloptera species Female; anterior end X10 Fig. (18): Physaloptera species Female; posterior end X10
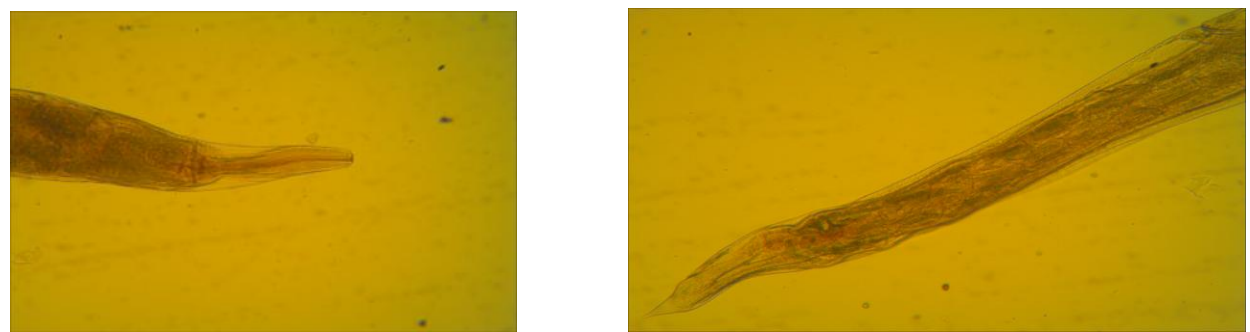

Fig. (19): Atractis species Female; anterior end X10 Fig. (20): Atractis species Female; posterior end X10 

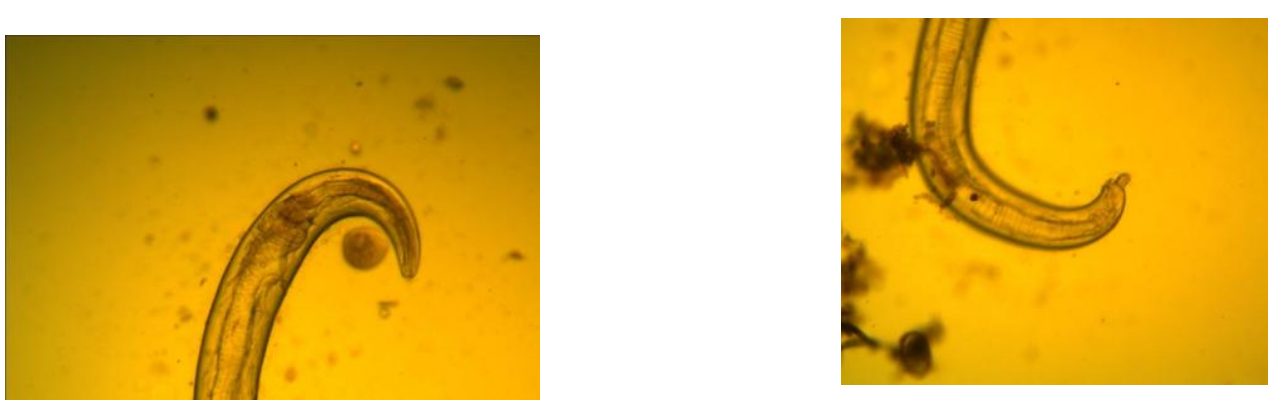

Fig. (21): Atractis species Male; anterior end X10 Fig. (22): Atractis species Male; posterior end X10
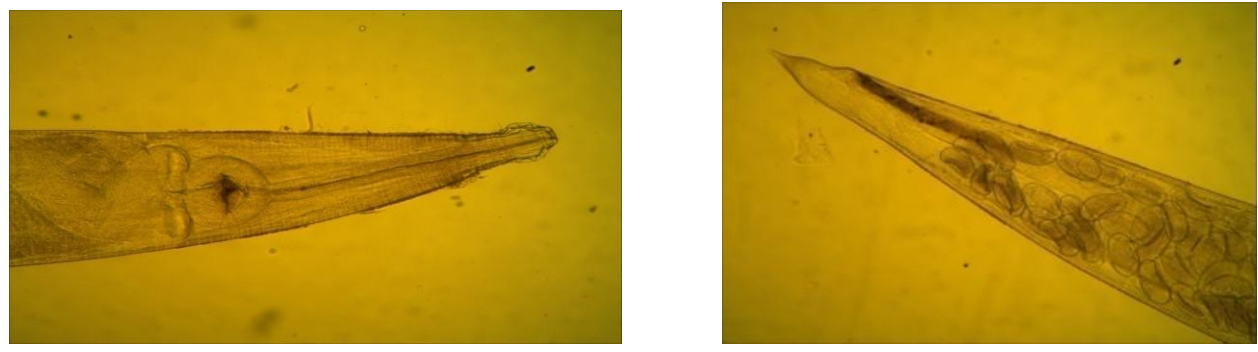

Fig. (23): Mehdiella microstoma Female; anterior end X10 Fig. (24): Mehdiella microstoma Female; posterior end X10
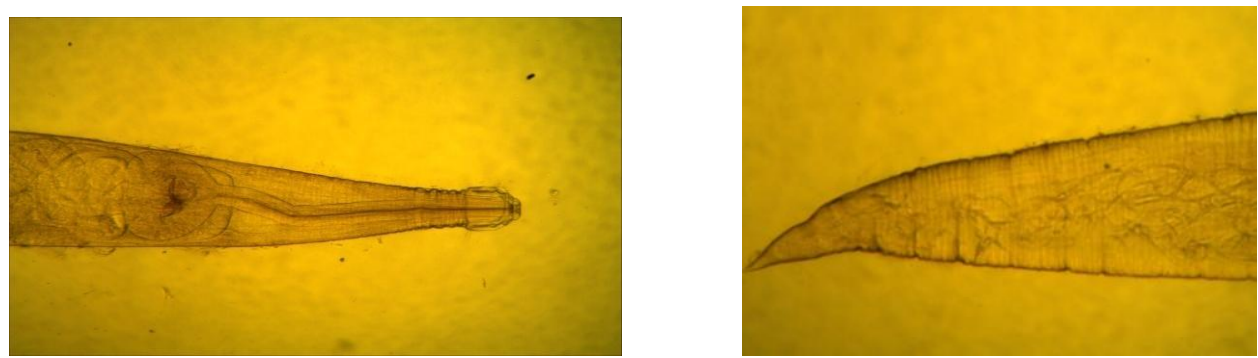

Fig. (25): Mehdiella species Female; anterior end X10 Fig. (26): Mehdiella species Female; posterior end X10
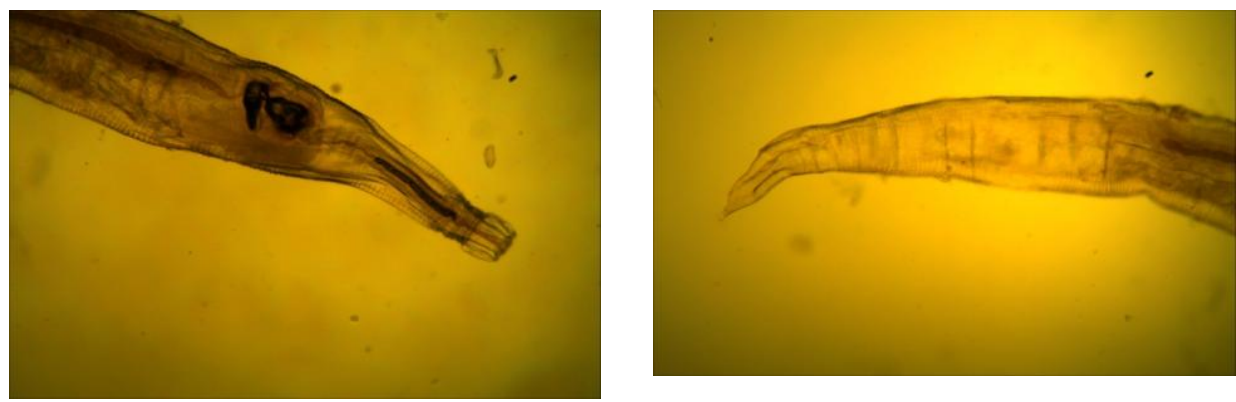

Fig. (27): Mehdiella species Male; anterior end X10 Fig. (28): Mehdiella species Male; posterior end X10 

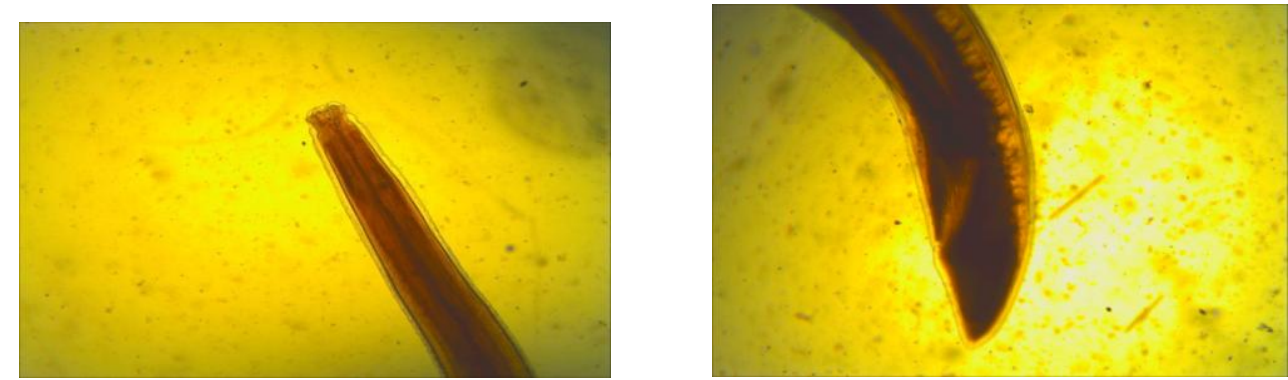

Fig. (29): Anguisticaecum holopterum Female; anterior end X10 Fig. (30): Anguisticaecum holopterum Female; posterior end X10
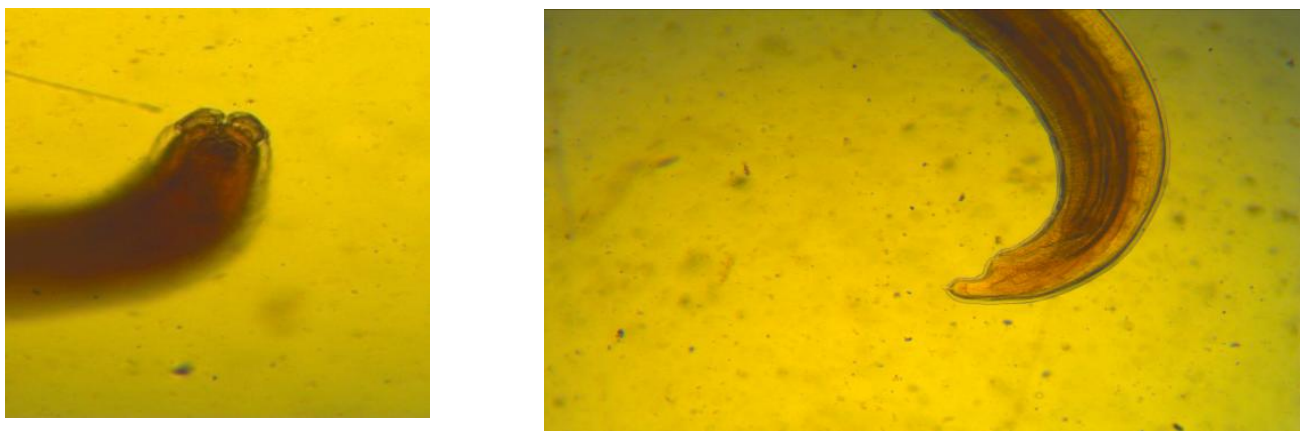

Fig. (31): Anguisticaecum holopterum Male; anterior end X10

Fig. (32): Anguisticaecum holopterum Male; posterior end X10

\section{Conclusion}

In this study, it was noticed that enormous number of nematode parasites were identified in apparently healthy tortoises, although, they were collected from different localities vary wildly in management. This agreed with Ellis and Seal (1996) who reported that, the wild animals become very susceptible to many sorts of infection in captivity.

Regular parasitological examination for Egyptian tortoises should be done and providing tortoises with clean suitable food and improving their environmental conditions to conserve this valuable pet animal.

\section{References}

Adamson, M.L. and Nasher, A.K. (1984):

Pharyngodonidae (Oxyuroidea Nematoda) of Agama yemenensis in Saudi Arabia hypothesis on the origin of pharyngodonids of herbivorous reptiles. Systematic Parasitology, 6: 299-318.

Baker, J.O.; Dickinson, V.M.; Leathers, C.H. and Devos, J.R. (1998): A potential parasite in wild tortoises in Arizona: Pinworm, Trematode and Fungus. 23th 
Annual Meeting and Symposium of the Desert Tortoise Council (abstract), Phoenix, Arizona.

Barnard, S.M. and Upton, S.J. (1994): A Veterinary Guide to the Parasites of Reptiles. Protozoa, 1: 155.

Barus, V. and Johnson, S. (1973): Notes on Mehdiella microstoma from Testudo hermanni, Folia Parasitology, 20: 139-140.

Baylis, H.A. (1920): On the classification of the Ascaridae. The systematic value of certain characters of the alimentary canal. Parasitology, 12: 253-264.

Bisset, S.A.; Vlassoff, A.; Doch, P.G.C.; Jonas, W.E.; West, C.J. and Green, R.S. (1996): Nematode burdens and immunological responses following natural challenge in Romney lambs selectively bred for low or high fecal worm egg count. Veterinary Parasitology, 61: 249-263.

Bouamer, S. and Morand, $S$. (2002): Description of Tachygonetria combesi $\mathrm{n}$. Sp. and redescriptions of four species of Tachygonetria Wedl, 1862 (Nematoda: Pharyngodonidae), with a new diagnosis of the genus, Systematic Parasitology, 53: 121139.

Dove, A.; Vergles, R. A.; Golja, J.; Vlahović, K.; Pavlak, M.; ZormanRojs, O. and Račnik, J. (2002): Treatment of endoparasitosis in tortoises on big farm in Slovenia. In Zbornik radova znanstveno stručnog savjetovanja smeđunarodnom sudjelovanjem:
17-20 October 2002; Rovinj, Balenović T. Zagreb (Ed): Znanstveno stručno savjetovanje međunarodnim sudjelovanjem "Veterinarski dani", 74-75.

Ellis, S. and Seal, S.V. (1996): Wildlife management and ecology. BSG News, 7(1): 10-12.

Forstner, M.J. (1960): Ein Beitrag zur Kenntnis parasitischer Nematoden aus griechischen Landschildkröten. Parasitenkd, 20: 1-22.

Holt, P.E; Cooper, J.E. and Needham, J.R. (1979): Diseases of tortoises: a review of seventy cases. Journal of Small Animal Practice, 20: 269-286.

Jacobson, E.R. (2007): Parasites and parasitic diseases of reptiles. In: Infectious diseases and pathology of reptiles (Jacobson, E.R., Ed.). CRC Press, Florida USA, 571-666.

Levine, N. D. (1985): Veterinary Protozoology, First (Ed.), the Iowa State University Press, Ames Iowa, USA.

Mader, D.R. (1996): Reptile medicine and surgery Philadelphia: W.B. Saunders.

Markov, G.S.; Ivanov, V.P.; Nikulin, V.P. and Chernobai, V.F. (1962): Helminth parasites of reptiles from the Volga-Delta and Caspian steppe, Trudy Astrakhanskogo Zapovednika, 6: 145-172.

Mitchell, M.A. and Figueroa, $O$. (2005): Clinical reptile gastroenterology. Veterinary Clinics of North America: Exotic Animal Practice, 8: 277-298. 
Pannikar, N.K. and Sproston, N.G. (1941): Osmotic relations of some metazoan parasites. Journal of Parasitology, 33: 214-223.

Pasmans, F.; Blahak, S.; Martel, A. and Pantchev, N. (2008): Review, Introducing reptiles into a captive collection: The role of the veterinarian. The Veterinary Journal, 175: 53-68.

Pence, D.B. and Dowler R.C. (1979): Helminth parasitism in the badger, (Taxidea taxus) Schreber (1778), from the western Great Plains. Proceedings

Helminthologialc Society of Washington 46(2): 245-253.

Rataj, A.V.; Lindtner-Knific, R.; Vlahović, K.; Mavri, U. and Dovč, A. (2011): Parasites in pet reptiles, Acta Veterinaria Scandinavica, 53: 33.

Reid, W.M. (1962): Chicken and turkey tapeworm. Georgia Agricultural Experimental Station, 53-55.

Rideout, B.A; Montali, R.J.; Phillips, L.G. and Gardiner, C.H. (1987): Mortality of captive tortoises due to viviparous nematodes of the genus Proatractis (family Atractidae). Journal of Wildlife Disease, 23: 103-108.

Satorhelyi, $T$. and Sreter, $T$. (1993): Studies on internal parasites of tortoises, Hungarian Society of
Parasitologists, Department of Parasitology and Zoology, University of Veterinary Science, Budapest, 26: 51-55.

Sprent, J. (1980): Ascaridoid nematodes of amphibians and reptiles: Angusticaecum and Krefftascaris, Journal of Helminthology, 54: 55-73.

Thapar, G.S. (1925): Studies on the oxyurid parasites of reptiles. Journal of Helminthology, 3: 83-150.

Travassos, L. (1925): Contributions para o conhecimentodafauna helmintolojica dos batraquios do Brasil. Nematodeosintestinais. Sciencias Medicina, 3: 673-687.

Traversa, D.; Capelli, G.; Iorio, R.; Bouamer, S.; Cameli, A. and Giangaspero, A. (2005): Epidemiology and biology of nematodofauna affecting Testudo hermanni, Testudo graeca and Testudo marginata in Italy, Parasitology Research, 98: 14-20. Willette, F.M.; Wright, K.M. and Thode B.C. (1995): Select protozoal diseases in amphibians and reptiles. A report for the Infectious Disease Committee, American Association of Zoo Veterinarians. 5: 19-29.

Wilson, S.C and Carpenter, J.W. (1996): Endoparasitic Diseases of Reptiles. Seminars in Avian and Exotic Pet Medicine, 5(2): 64- 74. 


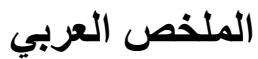

\section{مدى إنتشار الإصابة ببعض الايدان الخيطية في السلاحف المصرية (تستودو كلاينماني)

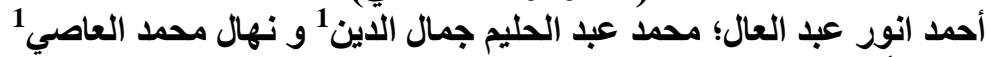

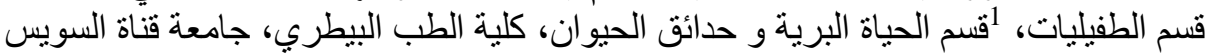

تم تجميع .0 سلحفاة من السلاحف المصرية و كانوا بصحة جيدة ظاهريا من مناطق مختلفة في

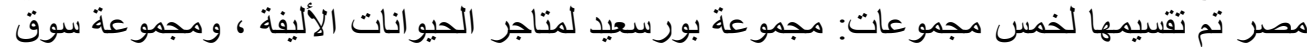

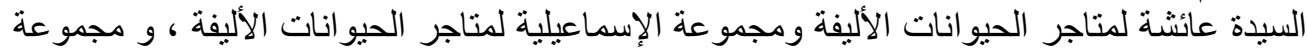

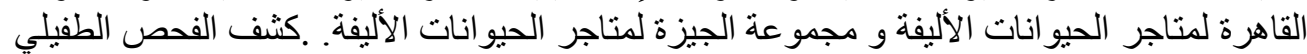

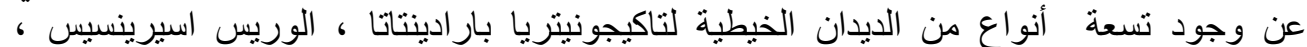

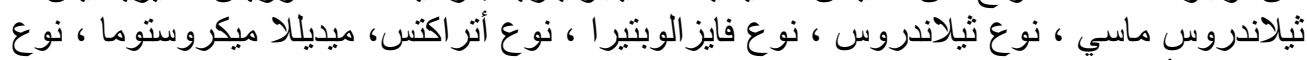

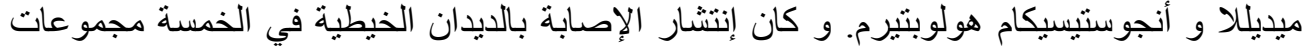

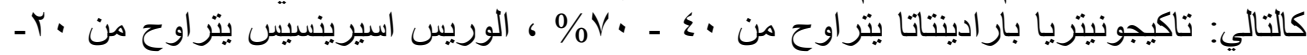

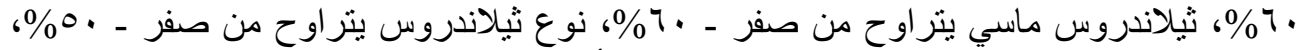

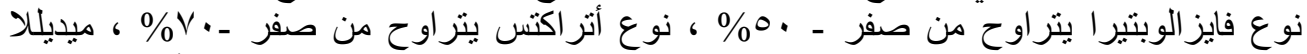

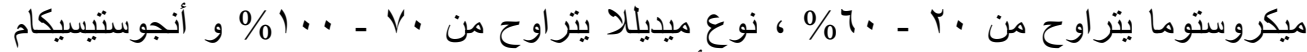

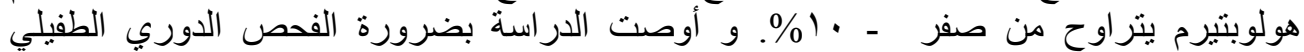
للسلاحف المصرية في الاسر و تحسين البيئة لهاو توفير ظروف معيشية جيدة حفاظا عليها. 